\title{
RIDGWAY'S RAILS CLIMBING SHRUBS AT HIGH TIDE
}

HIRAM RAFAEL MORENO-HIGAREDA, Pro Esteros, A.C. Departamento de Investigación, Calle Cuarta 210, Zona Centro, C.P. 22800, Ensenada, Baja California, México; moreno.hiram@uabc.edu.mx

GORGONIO RUIZ-CAMPOS, Facultad de Ciencias, Universidad Autónoma de Baja California, Carretera Transpeninsular Ensenada-Tijuana No. 3917, Colonia Playitas, C.P. 22860, Ensenada, Baja California, México (U.S. mailing address: PMB 064, P.O. Box 189003, Coronado, California 92178)

HORACIO DE LA CUEVA, Departamento de Biología de la Conservación, Centro de Investigación Científica y de Educación Superior de Ensenada, Carretera Transpeninsular Ensenada-Tijuana No. 3918, Pedregal Playitas, C.P. 22860, Ensenada, Baja California, México; cuevas@cicese.mx, cohevolution@gmail.com (corresponding author)

The Light-footed Ridgway's Rail (Rallus obsoletus levipes) is considered endangered in the United States under the Endangered Species Act of 1973 and is protected in Mexico under the Norma Oficial Mexicana (NOM-059-SEMARNAT-2010) as "in danger of extinction" ("P," DOF 2010, Ortiz-Pulido 2018). It is a cryptic species that inhabits coastal wetlands and lagoons from Santa Barbara, California, in the southwestern United States to Bahía de San Quintín in the northwest portion of the Baja California península, Mexico (Bent 1926, van Rossem 1929). This species is highly dependent for its survival on the halophytic vegetation cover provided by California cordgrass (Spartina foliosa) and pickleweed (Salicornia spp.) (Foin and Benchley-Jackson 1991). Here we describe an unreported, or at least uncommon, behavior for this species.

On 21 January 2019, at 07:00 during a rising tide (to 2.08 at 8:26, http// predmar.cicese.mx) we noticed six adult Ridgway's Rails perching together in a tall bush at Estero Punta Banda, located in Ensenada, Baja California, México, at $31^{\circ}$ $45^{\prime} 36^{\prime \prime} \mathrm{N}, 116^{\circ} 17^{\prime} 10^{\prime \prime} \mathrm{W}$ ( $<1 \mathrm{~m}$ above median sea level). The birds were perched approximately 1.80 meters above the marsh in a ngaio tree (Myoporum laetum), a species native to New Zealand, and one of the highest shrubs on the marsh. We had observed similar behavior at the site during previous high tides, including on 21 December 2016, when one rail was perching in desert broom (Baccharis sarothroides), and on 24 March 2018, when another was observed perching on California boxthorn (Lycium californicum); both plants are native species.

Eddleman and Conway (2018) referred to hopping or climbing behavior of Ridgway's Rail, in which birds may climb unto tall emergent plants, shrubs, or trees, especially in response to a reproduction of the species' call. However, our observations did not involve recorded calls, and suggest that the use of the highest shrubs at the Punta Banda marsh during high rising tides likely protects the birds not only from high waters, but that the shrubs also serve as a refuge from predators. Zembal et al. (1989) found that the rails they radio-tracked moved to higher ground during high tide. In finding survivorship around San Francisco Bay higher in areas of tall, dense cover of hybrid Spartina, Overton et al. (2014) showed that plant structure may facilitate the rails' persistence by providing cover during periods of tidal inundation. Any plans for removal of the invasive emergent shrubs at Estero Punta Banda should take this uncommon but possibly critical behavior of climbing into taller vegetation during high tides into account. We digitally recorded the 2019 observation on a Motorola G6 mobile phone, and have posted the recording at www.westernfieldornithologists.org/ V50A/RidgwayRail-video.mp4. 


\section{NOTES}

\section{LITERATURE CITED}

Bent, A. C. 1926. Life histories of North American marsh birds. U.S. Natl. Mus. Bull. 135.

DOF (Diario Oficial de la Federación). 2010. Norma Oficial Mexicana NOM059-SEMARNAT-2010. Protección ambiental-Especies nativas de México de flora y fauna silvestres-Categorías de riesgo y especificaciones para su inclusión, exclusión o cambio-Lista de especies en riesgo.

Eddleman, W. R., and Conway, C. J. 2018. Ridgway's Rail (Rallus obsoletus), in The Birds of North America (P. G. Rodewald, ed.), version 2.1. Cornell Lab Ornithol., Ithaca, NY; doi 10.2173/bna.ridrai1.02.1.

Foin, T. C., and Benchley-Jackson, J. L. 1991. Simulation model evaluation of potential recovery of endangered Light-footed Clapper Rail populations. Biol. Cons. 58:123-148; doi 10.1016/0006-3207(91)90116-Q.

Ortiz-Pulido, R. 2018. ¿Qué especies de aves están en riesgo en México? Huitzil 19:237-272; doi 10.28947/hrmo.2018.19.2.348.

Overton, C. T., Casazza, M. L., Takekawa, J., Strong, D. R., and Holyoak, M. 2014. Tidal and seasonal effects on survival rates of the endangered California Clapper Rail: Does invasive Spartina facilitate greater survival in a dynamic environment? Biol. Invasions 16:1897-1914; doi 10.1007/s10530-013-0634-5.

Van Rossem, A. J. 1929. The status of some Pacific coast Clapper Rails. Condor 31:213-215; doi 10.2307/1363336.

Zembal, R., Massey, B. W., and Fancher, J. M. 1989. Movements and activity patterns of the Light-footed Clapper Rail. J. Wildlife Mgmt. 53:39-42; doi $10.2307 / 3801302$.

Accepted 17 May 2019 